\title{
HLA-C wt Allele
}

National Cancer Institute

\section{Source}

National Cancer Institute. HLA-C wt Allele. NCI Thesaurus. Code C62759.

Human HLA-C wild-type allele is located in the vicinity of $6 \mathrm{p} 21.3$ and is approximately $3 \mathrm{~kb}$ in length. This allele, which encodes HLA class I histocompatibility antigen, Cw-1 alpha chain protein, plays a role in antigen presentation and the immune response. 